\title{
Nursing students' perceptions of their verbal and social interaction skills in Sweden and China during their first semester
}

Gunilla Lindqvist

School of Health and Caring Sciences, Linnaeus University, Växjö, Sweden, gunilla.lindqvist@Inu.se

$\mathrm{Li} \mathrm{Ge}$

Nursing College, Fujian University of Traditional Chinese Medicine, Fuzhou, Fujian, China, 2000005@fjtcm.edu.cn

Christel Borg

Department of Health, Blekinge Institute of Technology, Karlskrona, Sweden, christel.borg@bth.se

Zhu Xiaoling

School of Nursing, Wenzhou Medical University, Wenzhou, Zhejiang, China, xhb@wmu.edu.cn

Xu Hongbo

School of Nursing, Wenzhou Medical University, Wenzhou, Zhejiang, China, zxl@wmu.edu.cn

Jalal Safipour

School of Health and Caring Sciences, Linnaeus University, Växjö, Sweden, jalal.safipour@Inu.se

Mikael Rask

School of Health and Caring Sciences, Linnaeus University, Växjö, Sweden, mikael.rask@lnu.se

Follow this and additional works at: https://qane-afi.casn.ca/journal

Part of the Health and Physical Education Commons, and the Nursing Commons

\section{Recommended Citation}

Lindqvist, Gunilla; Ge, Li; Borg, Christel; Xiaoling, Zhu; Hongbo, Xu; Safipour, Jalal; and Rask, Mikael (2022) "Nursing students' perceptions of their verbal and social interaction skills in Sweden and China during their first semester," Quality Advancement in Nursing Education - Avancées en formation infirmière: Vol. 8: Iss. 1, Article 9.

DOI: https://doi.org/10.17483/2368-6669.1308

This International Perspective is brought to you for free and open access by Quality Advancement in Nursing Education Avancées en formation infirmière. It has been accepted for inclusion in Quality Advancement in Nursing Education - Avancées en formation infirmière by an authorized editor of Quality Advancement in Nursing Education - Avancées en formation infirmière. 


\section{Nursing students' perceptions of their verbal and social interaction skills in}

Sweden and China during their first semester

\section{Cover Page Footnote}

We are grateful and want to thank all the nursing students in their first semester who participated in this study. Nous remercions les étudiantes en sciences infirmières qui ont participé à cette étude lors de leur premier semestre, et nous leur en sommes très reconnaissantes. 


\section{Introduction}

The philosophical and theoretical content of the nursing discipline creates a basis for academic education and enables a professional and exclusive vision for nurses. It provides an overall understanding of people's lives and supports nurses to gain a greater awareness of the meaning of illness and health across a person's lifespan, which nurses need for evidence-based decision-making (Rega et al., 2017, p. 80). Nursing is a health profession in the caring sciences, which is relational by nature and applies a holistic approach towards individuals' well-being by considering all contextual environments (Turkel et al., 2018). Nursing education has basically two different components of knowledge: the theoretical and the practical. These need to be integrated into nursing education so that theoretical knowledge is applied correctly in each unique encounter with a patient (Ekebergh, 2018; Råholm et al., 2010) and that patients are the core of the curriculum (Salminen et al., 2010). These two main components are intended to improve students' ability to interact with patients in a professional manner and provide care based on the needs of individual patients (Kasch, 1986).

Assessing the quality of education and the progress of learning during nursing education is an essential task for health professionals to safeguard the quality of care (Oermann \& Gaberson, 2016). However, unlike with theoretical nursing knowledge, it is a challenge to assess the students' practical skills in terms of verbal and social interactions and their progress during their nursing education. Previous research has shown that there is a need for an adequate standard procedure in health care education to improve interpersonal communication skills (Bullington et al., 2019; Foronda et al., 2016). Although the importance of effective interactions and the creation of a trustful and caring relationship are well-established concepts in previous research (Östman et al., 2021), there appear to be no clear guidelines for their preparation and practice in nursing education.

The focus on nurse-patient interactions and how nursing students can develop their interpersonal communication skills in their nursing education is under rapid development and may develop in different ways around the world. To find out how nursing education is developing in different countries, it would be of interest to compare nursing education programs in two countries, such as Sweden and China. Are there differences between Swedish and Chinese nursing students in terms of their ages, work experience, and education in the first semester of their programs? Moreover, what can these programs learn from each other? To emphasize the importance of verbal and social interactions for nursing students and to create study guidelines for these interactions, it is essential to first study how students perceive the importance and frequency of nursing interactions and to identify students' educational needs.

\section{Background}

Findings from a recent literature review revealed that it is essential for nursing students to develop their communication skills to create good care relationships (Grant \& Jenkins, 2014). A basic component of patient encounters in the provision of safe care is good communication between the nurse and the patient (Jahromi Kargar \& Ramezanli, 2014). Moreover, it has been noted that environmental factors and cultural differences hinder the use of communication skills in practice (Chant et al., 2002). Studies involving nursing students indicated the significant importance of clinical preparation for interaction and communication in health care settings (Bullington et al., 2019; George et al., 2020). Verbal and social interactions, as forms of communication, are considered to be the key elements of a caring relationship between patients and health care providers that can be learned and improved during nursing education programs 
(Bach \& Grant, 2015; Rask \& Brunt, 2007). Effective and adequate interactions that build caring relationships are considered to be the first steps towards fulfilling the duties of the nursing profession (Bach \& Grant, 2015). It has also been shown in several studies from the patients' perspective that participating, being listened to, being respected, experiencing an understanding and caring attitude, and receiving hope and support from nurses are the aspects of care that influence patients' perceptions of the quality of that care (Browall et al., 2013; Ferrell et al., 2016; Grover et al., 2018; Lundberg et al., 2020).

When comparing nursing education programs in two countries, such as Sweden and China, it is important to be aware that nursing education programs differ worldwide. These differences are based on different education systems and academic cultures, which can create a challenging environment for academic collaboration (Deng, 2015; Salminen et al., 2010). It is also important to address the fact that there are cultural differences between Sweden and China that could affect what nursing programs see as important, as well as on which value systems they base their actions. It has been maintained (Knafo et al., 2011) that individuals in different countries vary in terms of their cultural value systems, which consist of the socially shared ideas that influence how people make their choices, which actions they perform, and how they behave. For example, Hofstede (2010) showed that the concepts of individualism and collectivism are the most important constructs to use for examining the cultural differences between countries. Hofstede (2010) showed that Sweden can be regarded as being a country that is much more individually oriented than China.

Nursing education in Sweden has been reformed several times over the years, and the link between education and research has been given greater prominence. A university reform was implemented in 1977, in which it was stated that nursing education should be based on scientific knowledge (Swedish Statute Book, 1977). A revision was carried out in 1993, when it was decided that all college-level nursing education programs would lead to both a professional degree as a registered nurse and a bachelor's degree in caring science and/or nursing science. The educational requirements currently consist of a three-year college program comprising 180 European Credit Transfer and Accumulation System (ECTS) credits (SFS, 1993; Socialstyrelsen, 2020), and both a professional degree and an academic bachelor's degree are included in the three-year program (SFS, 1993). The National Agency for Higher Education continually reviews the nursing programs in Sweden; although, to a certain extent, universities are free to create their own curricula based on the common national goals. Students should graduate with specific skills and abilities, such as being able to make independent and critical assessments, follow the development of knowledge, and exchange information at the scientific level (SFS, 1993).

Students at one university located in the southern part of Sweden, for example, begin their first semester by taking a course in the introduction to the nursing profession. The course objectives are for students to define and describe core care science concepts and theories and their significance for nursing. Students should be able to describe the growth and development of the nursing profession and define nurses' core competencies in relation to their professional function. Furthermore, they must be able to describe and reflect on the ethical and professional approach used in nursing. Students then move on to study anatomy, physiology, and microbiology while at the same time learning about the nursing profession. Students learn to apply the nursing process and documentation procedures from a patient's perspective and in relation to current evidence. Additionally, they learn about national guidelines, constitutions, general advice and important instructions for the nursing process, care technology, safety, and quality in care and caring 
documents. Course content may vary between different universities in Sweden, but all nursing education programs are based on the common national goals.

The bachelor's degree in nursing education in China is a four-year program or a five-year program for students who have completed senior high school. According to the National Standards for Nursing Teaching Quality (Teaching Guidance Committee of Higher Education, Ministry of Education, 2018), the goal of the bachelor's degree in nursing is to train students to meet the needs of China's socialist modernization and the development of health care. Furthermore, the goals of education include developing students' morals, intellect, and aesthetics, and enabling them to master the basic theories, knowledge, and skills of nursing. After completing the bachelor's degree in nursing, students have basic clinical nursing, teaching, management, scientific research, and innovation skills, and they can work as nurses and provide health care services at medical and health care institutions. To achieve these goals, the national standards provide macro-level guidance on the classification of subject programs, identifying five categories of educational programs. The programs must be developed for the undergraduate nursing degree, specifically including basic public education courses (e.g., computers, foreign languages, politics, philosophy); basic medical courses (e.g., anatomy, physiology, medical immunology, pharmacology); specialized nursing courses (e.g., basic nursing, health assessment, medical nursing, surgical nursing), nursing humanities, and social science courses (e.g., nursing ethics, nursing psychology, nursing management, interpersonal communication); and professional practice in nursing (practice in clinical departments and community health centres). The curricula can differ to reflect the characteristics of each university.

Students at the two Chinese universities participating in this study had completed courses in nursing psychology and an introduction to nursing during the first semester. They had learned some nursing theory and had gained knowledge about interpersonal relationships. Students at one university had been to the hospital to practise their knowledge from the two completed courses on two occasions, while those at the other university also studied human anatomy, histology, and medical biology, as well as ethics and legislation relevant to nursing.

A systematic review conducted with a critical analysis of the literature showed that newly graduated nurses from a wide range of countries, such as Dubai, the United Kingdom, the United States, Canada, Australia, Sweden, and China, felt unprepared for their work duties. Moreover, they had not had sufficient time to develop their clinical skills in practice, which resulted in their inability to provide quality care services to patients at the beginning of their careers and a loss of confidence (Monaghan, 2015). Ortiz (2016) found that newly graduated nurses were not adequately prepared during their education for their transition from student to nurse; thus, they needed to develop self-confidence in their ability to provide care. Studies have shown that newly graduated nurses lack support, guidance, and the opportunity to discuss concerns with their colleagues when they feel unsafe and when that they feel inadequately prepared in certain situations, such as during staff shortages (Camveren et al., 2020; Ortiz, 2016; Parker et al., 2014; Rolt \& Gillett, 2020). If the work environment of the newly graduated nurses is supportive, it facilitates the transition from being a student to being a nurse who is able to work independently (Hussein et al., 2019; Spiva et al., 2013). Newly graduated nurses enter a complex work environment with patient responsibility, and they are expected to cope with it with limited preparation; thus, the support they receive will have a positive impact on patient safety (Cope et al., 2019; Källberg et al., 2017). Studies showed that there was a direct relationship between nurses with a higher level of education and increased well-being and the survival rates for patients (Aiken 
et al., 2012; Aiken et al., 2014). The present study thus aimed to investigate the similarities and differences in first-semester nursing students' views on verbal and social interaction skills while at universities in Sweden and China, two countries with different educational systems.

\section{Method}

The present study used a cross-sectional design to investigate Swedish and Chinese nursing students' views on verbal and social interaction skills in their nursing education. The present study is also a part of a larger study with the aim to follow the students' development in their education. The Ethical Advisory Board of Southeast Sweden was consulted for the Swedish part of the study, and no ethical obstacles were found (Dnr EPK 381-2016). The ethical considerations for the Chinese part of the study were guided by the Standards and Operational Guidance for the Ethical Review of Health-Related Research with Human Participants (World Health Organization [WHO], 2011). Both the Swedish and the Chinese parts of the study were conducted in accordance with the Declaration of Helsinki (World Medical Association, 2013). All 797 participants received written and verbal information about the purpose and the procedures of the research, including the voluntary nature of participation and the option to withdraw at any time, before giving their written consent when completing the questionnaire. The confidentiality of the participants was assured; no names are mentioned in the text.

\section{Data Collection}

This study was conducted among nursing students during the first semester of their education at one university in southern Sweden and two universities in China before their clinical placement. At one of the Chinese universities, students had been on a field study for a short period of time before the study was conducted in their first semester. Data were collected by teachers at the universities, who were not directly involved in the education of the students in the program. A total of 950 first-semester students were asked to participate in this study (all nursing students at the Swedish university were asked and $60 \%$ of the students at the two Chinese universities were asked). Of these, 797 (83\%) completed the Verbal and Social Interactions for Nursing Students (VSI-NS) questionnaire (Table 1). The instruments were administered in the dominant language in each relevant country: Swedish or Mandarin. The Mandarin version was translated from English to Mandarin and from Mandarin back to English by two independent translators, and the designer of the questionnaire performed a final check. There were 689 female students and 108 male students; the mean age was 21.6 years.

\section{Table 1}

Demographic Characteristics of 797 Nursing Students from Three Universities, One in Sweden and Two in China

\begin{tabular}{lc|c|c}
\hline & Total & $\begin{array}{c}\text { Swedish } \\
\text { university }\end{array}$ & $\begin{array}{c}\text { Two Chinese } \\
\text { universities }\end{array}$ \\
\hline Number & 797 & 123 & 674 \\
\hline Sex & & & \\
Female & $689(86.4 \%)$ & $105(85.4 \%)$ & $584(86.6 \%)$ \\
Male & $108(13.6 \%)$ & $18(14.6 \%)$ & $90(13.4 \%)$
\end{tabular}


Previous education in the nursing sector

Previous experience of working in the nursing sector

Age (mean years, $S D)$
$90(11.3 \%)$

$175(21.9 \%)$

$21.6(4.7)$
$41(33.6 \%)$

$85(69.1 \%)$

$49(7.3 \%)$

$90(13.4 \%)$

The first part of the questionnaire contained questions about sociodemographic factors, such as age, sex, previous education in health care, and previous experience working in health care. The second part was the VSI-NS questionnaire, which was originally developed to survey patients' and nurses' views on the frequency and importance of nursing interactions in psychiatric care contexts (cf. Brunt \& Rask, 2018; Rask \& Brunt, 2006). The VSI-NS is a modified version of the original VSI and adjusted for the context of nursing education measuring different aspects of nurses' clinical skills. Eight teachers, all working within nursing education, modified the items (Rask et al., 2018). The VSI is described as a model of verbal and social interactions that is rooted in caring science; for further details of the model see Rask and Brunt (2007). The VSI-NS showed satisfactory psychometric properties in terms of content validity, construct validity, and internal consistency reliability, where the Cronbach's alpha for the four factors ranged between 0.81 and 0.89 in previous validation studies of the Swedish (Rask et al., 2018) and the Chinese (M. Zhang et al., 2019) versions of VSI for nursing students. It was also found that the questionnaire reflected the original conceptual model and could serve as a theoretical foundation to explain and understand nurses' caring interactions with their patients. The VSI-NS contains 31 items organized in four distinct factors: Inviting to talk about feelings and thoughts, Building a caring relationship, Encouraging social and practical aspects in daily life and Caring towards health and well-being (Rask et al., 2018; M. Zhang et al., 2019). Students are asked to assess both how frequently occurring each item was and how important they perceived it to be using a Likert-like scale, with the response format ranging from not at all (1) to a very high degree (4).

\section{Statistics}

Percentages were calculated for the individual items and the Likert scores of 3 and 4 were collapsed to the "high" category for the descriptive statistics. A mean value was calculated for each category for the factor level descriptive by adding the responses belonging to the same category divided by the number of items included in each category. The independent samples Mann-Whitney $U$ test was used to analyze the differences between the two countries in terms of the nursing students' views on verbal and social interaction skills, and between the female and male nursing students' views on the factors in VSI-NS. Linear regression analysis was used to investigate the background variables' impact on the four types of caring interactions. SPSS for Windows version 26.0 software (SPSS Inc., Chicago, IL, USA) was used for the statistical analysis.

\section{Results}

The study's findings showed that nursing students in their first semester, both in general and in the comparisons between Sweden and China, perceived that Caring towards health and well-being and Building a caring relationship were the most frequent and important types of caring interactions (Table 2).

\section{Table 2}


Comparison of How Nursing Students Perceive the Frequency and Importance of the VSI Factors, Mean Values (SD)

\begin{tabular}{lcccc|ccccc}
\hline & \multicolumn{4}{c|}{ Frequency mean $(S D)$} & \multicolumn{5}{c}{ Importance mean $(S D)$} \\
\hline & Total & $\mathrm{U} 1$ & $\mathrm{U} 2$ & $p$ value & Total & $\mathrm{U} 1$ & $\mathrm{U} 2$ & $p$ value \\
\hline Inviting to talk about & 2.50 & 2.57 & 2.48 & .063 & 2.89 & 2.94 & 2.89 & .364 \\
feelings and thoughts & $(.6)$ & $(.5)$ & $(.6)$ & & $.6)$ & $(.5)$ & $(.6)$ & \\
Caring towards health & 3.05 & 3.14 & 3.03 & .089 & 3.23 & 3.50 & 3.18 & $\mathbf{. 0 0 0}$ \\
and well-being & $(.6)$ & $(.5)$ & $.6)$ & & $.6)$ & $(.4)$ & $. .6)$ & \\
Building a caring & 3.04 & 3.29 & 3.00 &. $\mathbf{0 0 0}$ & 3.36 & 3.69 & 3.30 & $\mathbf{. 0 0 0}$ \\
relationship & $(.5)$ & $(.5)$ & $(.5)$ & & $(.6)$ & $(.3)$ & $(.6)$ & \\
Encouraging social & 2.72 & 2.64 & 2.72 & .413 & 2.98 & 3.12 & 2.95 & $\mathbf{. 0 0 3}$ \\
aspects in daily life & $(.6)$ & $(.6)$ & $(.6)$ & & $(.6)$ & $(.5)$ & $(.6)$ & \\
\hline
\end{tabular}

Note. $\mathrm{U} 1=$ Swedish university, $\mathrm{U} 2=$ two Chinese universities.

Bold figures are significant at $<.05$.

There were differences between how the female and male students perceived the frequency of Building a caring relationship; the male students perceived it to occur less frequently than did the female students (Table 3 ). 


\section{Table 3}

Comparison of How Female and Male Nursing Students Perceive the Frequency and Importance of the VSI Factors, Mean Values (SD), and Comparison of Swedish and Chinese Female Nursing Students and Swedish and Chinese Male Nursing Students

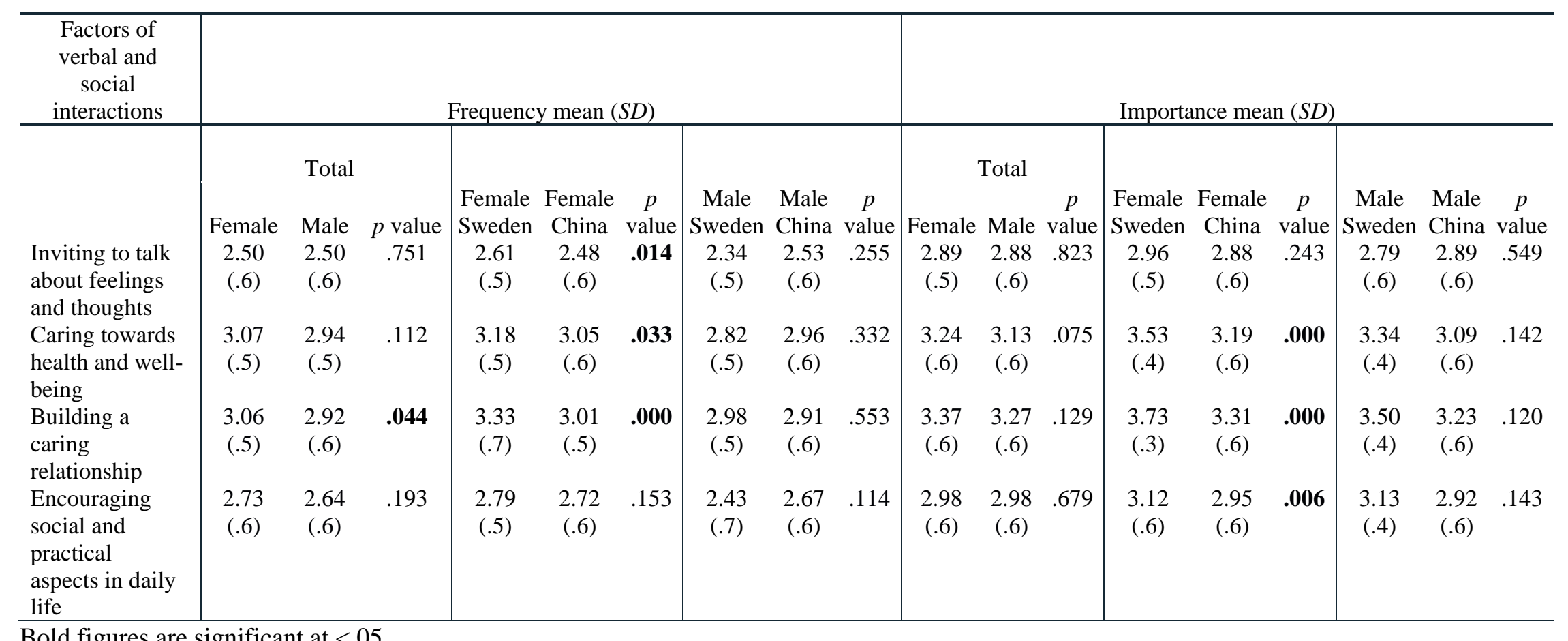

Bold figures are significant at $<.05$. 
The differences between the female and male students were significant in the Swedish sample but not in the Chinese sample (Table 4).

\section{Table 4}

Comparison of How Female and Male Nursing Students in Sweden and in China Perceive the Frequency and Importance of the VSI Factors

\begin{tabular}{l|cc|cc}
\hline & \multicolumn{2}{|c|}{ Frequency mean $(S D)$} & \multicolumn{2}{|c}{ Importance mean $(S D)$} \\
\hline & Sweden & China & Sweden & China \\
& $p$ value & $p$ value & $p$ value & $p$ value \\
\hline Inviting to talk about feelings and thoughts & .085 & .295 & .357 & .866 \\
Caring towards health and well-being & $\mathbf{. 0 1 8}$ & .437 & .057 & .159 \\
Building a caring relationship & $\mathbf{. 0 3 6}$ & .211 &. $\mathbf{0 3 5}$ & .357 \\
Encouraging social aspects in daily life & $\mathbf{. 0 2 3}$ & .660 & .860 & .639 \\
\hline
\end{tabular}

Bold figures are significant at <.05.

The comparisons between the female students in the Swedish sample and the female students in the Chinese sample revealed several significant differences, although no significant differences were found for the corresponding comparison for male students (Table 3). The Chinese female students perceived the frequency of the occurrence of Inviting to talk about feelings and thoughts, Caring towards health and well-being, and Building a caring relationship as significantly lower than the Swedish female students did.

The investigation of which background variables had the greatest impact on each of the four types of caring interactions showed that the country (Sweden or China) had a significant influence on how students perceive the frequency of Caring towards health and well-being and Building a caring relationship. Furthermore, it was found that the country (Sweden or China) had a significant influence on how students perceived the importance of Caring towards health and well-being, Building a caring relationship, and Encouraging social aspects in daily life. Students who had previous education within the nursing sector rated the frequency and importance of Building a caring relationship and the importance of Inviting to talk about feelings and thoughts higher than did those without previous education in the nursing sector. Additionally, the older the students were, the more important they perceived that Caring towards health and well-being was (Table 5). 


\section{Table 5}

Linear Regression Analysis of the Four Factors of Verbal and Social Interaction Skills (p values)

\begin{tabular}{|c|c|c|c|c|c|c|c|c|c|c|c|c|c|c|c|c|}
\hline & \multicolumn{8}{|c|}{ Frequency } & \multicolumn{8}{|c|}{ Importance } \\
\hline & \multicolumn{2}{|c|}{$\begin{array}{l}\text { Inviting to talk } \\
\text { about feelings } \\
\text { and thoughts }\end{array}$} & \multicolumn{2}{|c|}{$\begin{array}{l}\text { Caring towards } \\
\text { health and } \\
\text { well-being }\end{array}$} & \multicolumn{2}{|c|}{$\begin{array}{l}\text { Building a caring } \\
\text { relationship }\end{array}$} & \multicolumn{2}{|c|}{$\begin{array}{l}\text { Encouraging } \\
\text { social and } \\
\text { practical } \\
\text { aspects in } \\
\text { daily life }\end{array}$} & \multicolumn{2}{|c|}{$\begin{array}{l}\text { Inviting to talk } \\
\text { about feelings } \\
\text { and thoughts }\end{array}$} & \multicolumn{2}{|c|}{$\begin{array}{l}\text { Caring towards } \\
\text { health and well- } \\
\text { being }\end{array}$} & \multicolumn{2}{|c|}{$\begin{array}{l}\text { Building a caring } \\
\text { relationship }\end{array}$} & \multicolumn{2}{|c|}{$\begin{array}{c}\text { Encouraging } \\
\text { social and } \\
\text { practical } \\
\text { aspects in daily } \\
\text { life }\end{array}$} \\
\hline & beta & $t$ & beta & $t$ & beta & $t$ & beta & $t$ & beta & $t$ & beta & $t$ & beta & $t$ & beta & $t$ \\
\hline Sex & -.027 & -.42 & .100 & 1.63 & .113 & 1.96 & .063 & .94 & .012 & .18 & .116 & 1.96 & .094 & 1.62 & .007 & .11 \\
\hline Age & -.005 & -.99 & -.007 & -1.31 & .002 & .46 & -.005 & -.94 & .003 & .54 & $-.017 * *$ & -3.41 & -.002 & -.42 & -.010 & -1.74 \\
\hline $\begin{array}{l}\text { Previous } \\
\text { education within } \\
\text { the nursing sector }\end{array}$ & .006 & .09 & -.017 & -.25 & $-.132 *$ & -1.98 & -.009 & -.12 & $-.253 * *$ & -3.33 & .018 & .27 & $-.197 *$ & -2.91 & -.101 & -1.37 \\
\hline $\begin{array}{l}\text { Previous } \\
\text { experience } \\
\text { working as a } \\
\text { nurse without } \\
\text { special } \\
\text { preparation }\end{array}$ & .000 & .01 & .010 & .63 & -.014 & -.93 & .006 & .34 & -.010 & -.54 & .009 & .59 & .001 & .09 & -.013 & -.79 \\
\hline Sweden vs China & -.118 & -1.66 & $-.145^{*}$ & -2.15 & $-.241 * * *$ & -3.83 & -.064 & -.86 & .032 & .44 & $-.424 * * *$ & -6.59 & $-.364 * * *$ & -5.79 & $-194 * *$ & -2.76 \\
\hline$R$ & & & .1 & & .22 & & .05 & & .13 & & .259 & & .287 & & .13 & \\
\hline Adjusted $R^{2}$ & & & .0 & & .04 & & -.0 & & .01 & & .061 & & .076 & & .01 & \\
\hline
\end{tabular}

$$
* p<.05 . * * p<.01 . * * * p<.001 \text {. }
$$


A closer investigation of the four factors (Table 6) revealed that in terms of Inviting to talk about feelings and thoughts, the most frequently occurring and important caring interactions were to talk to the patients about how they perceive their personal problems and difficulties and to talk to the patients about how they experience their illness; the Chinese students perceived the interactions as occurring less frequently than did the Swedish students.

\section{Table 6}

How First-Semester Nursing Students Perceive the Frequency and Importance of the VSI Factors, Percentage of Affirmative Answers (3 and 4, High Degree and Very High Degree)

\begin{tabular}{|c|c|c|c|c|c|c|}
\hline \multirow[t]{2}{*}{ Items of VSI } & \multicolumn{3}{|c|}{ Frequency } & \multicolumn{3}{|c|}{ Importance } \\
\hline & Total & Sweden & China & Total & Sweden & China \\
\hline \multicolumn{7}{|l|}{ Factor 1: Inviting to talk about feelings and thoughts } \\
\hline $\begin{array}{l}\text { Talk to the patients about things/situations that } \\
\text { they seem to be embarrassed about or feel bad } \\
\text { about }\end{array}$ & 32.7 & 33.0 & 32.6 & 59.0 & 60.3 & 58.8 \\
\hline $\begin{array}{l}\text { Talk to the patients about things/situations that } \\
\text { they experience as unpleasant and seems to make } \\
\text { them feel sad }\end{array}$ & 39.2 & 41.1 & 38.9 & 61.7 & 67.7 & 60.4 \\
\hline $\begin{array}{l}\text { Talk to the patients about things/situations that } \\
\text { they seem to experience as frightening }\end{array}$ & 41.8 & 48.3 & 40.6 & 63.8 & 69.2 & 62.8 \\
\hline Talk to the patients about their sexuality & 20.0 & 10.4 & 21.6 & 39.1 & 33.0 & 40.1 \\
\hline $\begin{array}{l}\text { Talk to the patients about how they think and feel } \\
\text { about other people }\end{array}$ & 50.2 & 48.3 & 51.8 & 69.2 & 70.0 & 69.1 \\
\hline $\begin{array}{l}\text { Talk to the patients about things/situations that } \\
\text { they seem to experience as unpleasant to talk } \\
\text { about }\end{array}$ & 34.9 & 33.0 & 35.1 & 66.0 & 53.7 & 68.2 \\
\hline $\begin{array}{l}\text { Talk to the patients about situations they have } \\
\text { experienced earlier in life }\end{array}$ & 59.5 & 68.7 & 58.0 & 69.2 & 76.7 & 71.8 \\
\hline $\begin{array}{l}\text { Talk to the patients about how they perceive their } \\
\text { personal problems and difficulties }\end{array}$ & 64.9 & 72.0 & 63.7 & 82.3 & 90.1 & 80.8 \\
\hline $\begin{array}{l}\text { Talk to the patients about how they experience } \\
\text { their illness }\end{array}$ & 73.4 & 83.1 & 71.7 & 85.2 & 95.1 & 85.4 \\
\hline \multicolumn{7}{|l|}{ Factor 2: Caring towards health and well-being } \\
\hline $\begin{array}{l}\text { Support patients to engage in physical exercise } \\
\text { that benefits their health and well-being }\end{array}$ & 84.6 & 83.8 & 84.7 & 82.7 & 92.6 & 81.0 \\
\hline $\begin{array}{l}\text { Inform and support patients to eat and drink } \\
\text { healthily }\end{array}$ & 84.1 & 78.8 & 85.0 & 89.5 & 92.6 & 89.0 \\
\hline $\begin{array}{l}\text { Encourage/support patients in coping with daily } \\
\text { life through routines and keeping in order the } \\
\text { things they need }\end{array}$ & 71.9 & 82.5 & 70.1 & 73.8 & 93.3 & 70.3 \\
\hline Talk to the patients about how they sleep & 77.1 & 67.5 & 79.7 & 78.5 & 89.4 & 74.5 \\
\hline $\begin{array}{l}\text { Talk to the patients about how they can manage } \\
\text { their medication }\end{array}$ & 70.7 & 79.5 & 69.2 & 78.5 & 95.9 & 75.3 \\
\hline Talk to the patients about their feelings & 76.3 & 69.9 & 76.8 & 83.4 & 90.8 & 82.1 \\
\hline
\end{tabular}




\begin{tabular}{|c|c|c|c|c|c|c|}
\hline \multirow[t]{2}{*}{ Items of VSI } & \multicolumn{3}{|c|}{ Frequency } & \multicolumn{3}{|c|}{ Importance } \\
\hline & Total & Sweden & China & Total & Sweden & China \\
\hline $\begin{array}{l}\text { Talk to the patients about how they/you together } \\
\text { find solutions to enhance their well-being }\end{array}$ & 84.6 & 90.5 & 71.7 & 89.8 & 100 & 88.0 \\
\hline $\begin{array}{l}\text { Encourage the patients to learn new practical } \\
\text { skills }\end{array}$ & 60.7 & 62.9 & 60.3 & 74.0 & 78.5 & 73.1 \\
\hline \multicolumn{7}{|l|}{ Factor 3: Building a caring relationship } \\
\hline $\begin{array}{l}\text { Show the patients that you want to get to know } \\
\text { them }\end{array}$ & 77.4 & 88.1 & 75.5 & 86.2 & 96.8 & 84.3 \\
\hline Show the patients that you care about them & 82.5 & 93.2 & 80.6 & 88.7 & 98.3 & 86.9 \\
\hline Show the patients that you are there for them & 83.3 & 93.2 & 81.6 & 89.8 & 99.2 & 88.1 \\
\hline Show the patients that they can trust you & 86.7 & 95.0 & 85.2 & 92.5 & 100 & 91.1 \\
\hline $\begin{array}{l}\text { Show the patients that you have time for them } \\
\text { and want to make contact with them }\end{array}$ & 68.0 & 74.6 & 76.8 & 81.3 & 93.7 & 79.0 \\
\hline Show the patients that you are honest & 86.5 & 95.7 & 84.9 & 90.8 & 99.2 & 89.3 \\
\hline $\begin{array}{l}\text { Remind the patients about positive experiences } \\
\text { from their past }\end{array}$ & 64.4 & 67.8 & 63.8 & 79.0 & 81.2 & 78.6 \\
\hline \multicolumn{7}{|l|}{ Factor 4: Encouraging social aspects in daily life } \\
\hline $\begin{array}{l}\text { Encourage the patients to do things with other } \\
\text { people }\end{array}$ & 70.3 & 73.9 & 70.1 & 79.2 & 87.5 & 79.7 \\
\hline $\begin{array}{l}\text { Show interest in the patients' social situation in } \\
\text { general }\end{array}$ & 55.3 & 68.1 & 53.1 & 59.3 & 81.6 & 55.4 \\
\hline $\begin{array}{l}\text { Encourage the patients to take part in group } \\
\text { activities }\end{array}$ & 65.6 & 69.0 & 65.1 & 76.1 & 73.5 & 76.6 \\
\hline $\begin{array}{l}\text { Talk to the patients about their experiences of } \\
\text { being together with other people }\end{array}$ & 48.7 & 47.0 & 49.0 & 66.2 & 65.8 & 66.3 \\
\hline $\begin{array}{l}\text { Encourage the patients to stay in contact with } \\
\text { their relatives and friends }\end{array}$ & 73.5 & 70.4 & 74.0 & 80.7 & 89.3 & 79.1 \\
\hline $\begin{array}{l}\text { Talk to the patients about possible difficulties they } \\
\text { have when being with other people }\end{array}$ & 46.6 & 41.0 & 47.6 & 63.1 & 66.1 & 62.5 \\
\hline $\begin{array}{l}\text { Talk to the patients about how they perceive } \\
\text { themselves }\end{array}$ & 54.0 & 47.9 & 55.1 & 68.7 & 77.3 & 68.3 \\
\hline
\end{tabular}

The least frequently occurring and the least important caring interaction was to talk to the patients about their sexuality; the Chinese students perceived it more frequently and viewed it as being more important than did the Swedish students. In Caring towards health and well-being the most frequent and important interactions were to support patients in engaging in physical exercise that benefits their health and well-being, to talk to the patients about how they/you together find solutions to enhance their well-being, and to inform and support patients to eat and drink healthily. To inform and support patients to eat and drink healthily, to talk to the patients about how they sleep, and to talk to the patients about their feelings were the interactions that were perceived as occurring more frequently by the Chinese students than by the Swedish students. In terms of Building a caring relationship, the most frequent and important interactions were show the patients 
that you care about them, show the patients that you are there for them, show the patients that they can trust you, and show the patient that you are honest. In terms of Encouraging social aspects in daily life, the most frequent and important interactions were to encourage the patients to do things with other people and to encourage the patients to keep in contact with their relatives and friends. The interactions that Chinese students perceived as occurring more frequently than the Swedish students did were to encourage the patients to stay in contact with their relatives and friends and to talk to the patients about possible difficulties they have when being with other people. The interaction that the Chinese students perceived to be more important than the Swedish students was to encourage the patients to take part in group activities.

\section{Discussion}

The results of this study show minor differences between the Swedish and the Chinese study populations, not only related to sociodemographic characteristics but also in terms of some aspects of self-reported verbal and social interaction (importance and frequency). The nursing students rated Caring towards health and well-being and Building a caring relationship as the most frequently occurring and most important factors in nursing care. The latter was perceived as more frequently occurring according to the Swedish students. The Swedish female students perceived three of the factors as occurring significantly more and felt they were more important than the Chinese students did.

In addition to the sociodemographic variables of age and previous education being significantly associated with the nursing students' view on Caring towards health and well-being and Building a caring relationship, the frequency and importance of these factors were rated higher by the Swedish students than by the Chinese students. These variations may be explained by differences in the study program and course syllabi in the first semester in these two countries. Nursing students in Swedish universities usually start their nursing program by taking basic theoretical nursing courses, with a focus on understanding how they can use nursing theories and core competencies in their daily work. The nursing students in China mainly focus on an introduction to nursing, nursing psychology, and basic medical courses, such as anatomy, during their first semester, and at one of the universities, they had been on a field study for a short period of time before the study was conducted in their first semester. The Chinese students' usually start focusing more on nursing skills in the second semester and may thus know less about Caring toward health and well-being and Building a caring relationship during their first semester.

The study's results show minor differences that could be related to the sociodemographic characteristics of two study populations in some of the aspects of the self-reported verbal and social interactions. Many of the students in Sweden had worked as an assistant nurse for a number of years. Previous experience as an assistant nurse is considered to be beneficial for nurses; it enables them to apply the knowledge they have already gained, such as specific practical knowledge, techniques, and procedures required to create a good caring relationship with patients (Gabrielsson et al., 2016; Garner et al., 2013). Students in China are directly enrolled in universities or colleges, and the majority do not have any work experience before completing senior high school. The majority of the study participants in both China and Sweden are female. This also follows the general pattern and nursing occupation traditions, in which the majority of nurses are female in many other countries (Petges \& Sabio, 2020; Whitford et al., 2020). Only 10\% of nurses employed worldwide are male (WHO, 2020). Thus, several differences in sociodemographic variables between the students in the two countries could explain the differences between them and influence students' views on clinical nursing skills. 
The results indicate that there are gender differences in how students perceive the frequency of Inviting to talk about feelings and thoughts, Caring towards health and well-being, and Building a caring relationship. These differences were not significant between the male students in each country. However, while the differences in the frequency and importance of the factors are significantly higher among the female Chinese and Swedish students than the male students in both countries, the scores were also significantly higher for the Swedish students than the Chinese students. Moreover, the differences and similarities between the Chinese and Swedish students were identified when it came to the frequency and importance of talking about feelings and thoughts in general. To talk to the patients about situations that they experience as frightening is rated as occurring significantly more frequently and as being more important among Swedish than Chinese students. The same is true for talking to the patients about how they perceive their personal problems and difficulties and how patients experience their illness. Although these interactions are essential parts of the nursing profession (Bullington et al., 2019; George et al., 2020), it seems that students in both study settings face some difficulties, especially when talking to patients about their sexuality. The frequency and importance of these interactions were higher among Chinese students in our study. This result is in line with the findings reported in a previous research study, in which talking about sexual health and sexual activity was identified as a difficult task for health care providers, which needs to be improved within primary care by facilitating greater involvement from nurses (Dyer \& das Nair, 2013). Wang et al. (2018) showed that discussing sexuality remains a cultural taboo, and nurses feel uncomfortable talking about it in clinical care settings in China. This concurs with Saunamäki and Engström's study (2013) in which they found that sexuality was a taboo subject and someone else's responsibility, so patients were referred to the doctor for sexuality-related matters. The study by Kong et al. (2009) showed that 97\% ( $n=139)$ of nursing students stated a need for strategies to prepare them to have sexual health conversations. As suggested by Saunamäki and Engström (2013), education in the area of sexual issues is necessary on a regular basis, both in nursing schools and as part of the in-service preparation in hospitals. Since the nursing students in the present study perceived talking about sensitive matters, such as feelings and thoughts, as the least important and least frequently occurring practical nursing skill, which has been found as problematic in several studies, nursing education needs to have a clear focus on how to handle such sensitive matters.

The goal of health care is to increase the health and well-being of patients. To achieve physical, social, and psychological well-being, patients need support from health care professionals. Nursing education in China has a more pronounced medical focus, and care is concerned with treating diseases. The students in Sweden learn almost from the first day about caring science/nursing science and that the nursing profession concerns working to improve the patient's health and involving the patient. The results show that the nursing students in Sweden thought it was more important than did their Chinese counterparts to talk to patients about how to find ways to enhance their well-being. An assumption based on this result may be that during the first semester of the Swedish nursing education program, the focus is on health/caring science/nursing science versus medicine, which may mean that the Swedish nursing students are better prepared to meet and communicate with patients. Sleep is a basic human need and is necessary for physical and mental recovery (Carrera-Hernández et al., 2018). The present study's results show that the Chinese students rated the frequency of talking to the patient about their sleep higher than did the Swedish students. However, the Swedish students considered it to be more important to talk about sleep than the Chinese students did. Gellerstedt et al. (2019) reported that Swedish students in their final year of education had not learned about sleep; it was not included 
in the course syllabus and was addressed only in other contexts and not focused on. However, the students in that study thought that sleep was important to learn about and should be treated in the same way as other issues, such as pain. Based on the present study, it is somewhat difficult to comment on the differences between the students in Sweden and in China in terms of why there was a higher frequency of talking about sleep with the patients in China and why the Swedish students found it more important to do. A further study is needed to fully understand these differences between Swedish and Chinese students.

When comparing how the female and male nurses perceived the frequency and the importance of the verbal and social interactions, the female and male students in the Swedish sample differed on several dimensions. Swedish female students rated three dimensions as significantly more frequent and one as significantly more important than the Swedish male students did, but there were no significant differences in the Chinese sample. Although caring has in the past been traditionally associated with the female gender and nurses are most often women (W. Zhang \& Liu, 2016), nurses' good communication skills (Bullington et al., 2019) have a greater impact than does gender from the patients' perspective (O'Lynn \& Krautscheid, 2011). Caring is traditionally associated with close interactions, communication, and touching, even in difficult situations where intimate touches by nurses is common (Halldorsdottir, 2008; Holopainen et al., 2019; O’Lynn \& Krautscheid, 2011). A possible way to understand the differences between the two countries could be that the Chinese male and female students perceived their role as nursing students as being more equal than the Swedish students did. To gain a greater understanding of the differences between male and female students' ratings of clinical nursing skills, further studies are needed in both countries.

The present study's findings show that there are differences between Swedish and Chinese students' view on the frequency and importance of clinical nursing skills on a group level. This could be an indication that the way in which care is given is related to the education system and to the culture, where differences can be influenced by the concepts of individualism and collectivism. Hofstede (2010) studied the concepts of individualism and collectivism and showed that Sweden can be regarded as being a much more individual-oriented country than China. According to Hanssen (2007), autonomy, independence, and the right to independence are important in the concept of individualism, while in collectivism, autonomy is to some extent subordinate to the group's expectations and obligations. It is difficult to state how much influence the education system, the culture, and the view of the caring relationship have had on the result of the present study, but further studies of nursing students' ideas about entering the nursing profession are needed in both countries.

From a methodological perspective, the low number of male participants in the present study could be a possible weakness. The comparisons between male and female nursing students should thus be interpreted with caution, although the sample is representative in terms of the majority of nursing students being female. The high proportion of participants in China and Sweden (relative to the total population size) is satisfactory for this study, and the results could be seen as representative of the target universities. The nature of a cross-sectional study did not allow the researchers to follow-up on the progress of the nursing students during their education. However, a comparison of first-year students with final-year students is recommended to gain knowledge about the impact that verbal and social interaction skills have on education and practice. The authors also recommend qualitative interview studies with both teachers and students to gain a greater understanding of the quality of nursing education, study guides, clinical practice, and 
personal factors that can influence the interaction skills and communication performance of students.

\section{Conclusion}

The study's results show that there are minor differences related to nursing students' views on verbal and social interaction skills and differences between genders and universities in Sweden and China. The results indicate that there are differences in first-semester students' views on the frequency and importance of Caring towards health and well-being and Building a caring relationship. It could be concluded that students perceive talking about sensitive matters, such as feelings, thoughts, and sexual health, as the least important part in nursing. However, research has pointed out that it is important for patients and that many nurses feel uncomfortable talking about it; nursing education thus needs to have a clear focus on how the students can develop their skills in talking about these matters.

Furthermore, since sleep is a contributory factor for a patient's health, nursing students need a broader knowledge base to be able to create good conditions for sleep. Nursing education thus needs to include more in-depth knowledge about sleep and how it can be promoted.

This study was conducted among first-semester nursing students; a longitudinal follow-up study would thus be preferable to identify students' development of their practical nursing skills. Additionally, qualitative in-depth studies would be suitable for gaining a greater understanding of how to improve students' verbal and social interaction skills through nursing education. 


\section{References}

Aiken, L., Cimiotti, J., Sloane, D., Smith, H., Flynn, L., \& Neff, D. (2012). Effects of nurse staffing and nurse education on patient deaths in hospitals with different nurse work environments. Journal of Nursing Administration, 42(10), 10-16. https://doi.org/10.1097/01.NNA.0000420390.87789.67

Aiken, L., Sloane, D., Bruyneel, L., Van den Heede, K., Griffiths, P., Busse, R., Diomidous, M., Kinnunen, J., Kózka, M., Lesaffre, E., \& McHugh, M. (2014). Nurse staffing and education and hospital mortality in nine European countries: A retrospective observational study. Lancet, 24, 1824-1830. https://doi.org/10.1016/S0140$\underline{6736(13) 62631-8}$

Bach, S., \& Grant, A. (2015). Communication \& interpersonal skills in nursing. Sage.

Browall, M., Koinberg, I., Falk, H., \& Wijk, H. (2013). Patients' experience of important factors in the healthcare environment in oncology care. International Journal of Qualitative Studies on Health \& Well-being, 8(1), 20870. https://doi.org/10.3402/qhw.v8i0

Brunt, D., \& Rask, M. (2018). Resident and staff perceptions of the content of their relationship in supported housing facilities for people with psychiatric disabilities. Journal of Multidisciplinary Healthcare, 11, 673-681.

Bullington, J., Söderlund, M., Bos Sparén, E., Kneck, Å., Omérov, P., \& Cronqvist, A. (2019). Communication skills in nursing: A phenomenological-based communication training approach. Nurse Education in Practice, 39, 136-141.

Camveren, H., Arslan Yürümezoğlu, H., \& Kocaman, G. (2020). Why do young nurses leave their organization? A qualitative descriptive study. International Nursing Review, 67(4), 519-528. https://doi.org/10.1111/inr.12633

Carrera-Hernández, L., Aizpitarte-Pejenaute, E., Zugazagoitia-Ciarrusta, N., \& Goñi-Viguria, R. (2018). Patients' perceptions of sleep in a critical care unit. Enfermería Intensiva (English ed.), 29(2), 53-63. https://doi.org/10.1016/j.enfie.2018.01.002

Chant, S., Jenkinson, T., Randle, J., \& Russell, G. (2002). Communication skills: Some problems in nursing education and practice. Journal of Clinical Nursing, 11(1), 12-21. https://doi.org/10.1046/j.1365-2702.2002.00553.x

Cope, V., Murray, M., \& Sundin, D. (2019). New graduate nurses' understanding and attitudes about patient safety upon transition to practice. Journal of Clinical Nursing, 28(13/14), 2543-2552. https://doi.org/10.1111/jocn.14839

Deng, F.-F. (2015). Comparison of nursing education among different countries. Chinese Nursing Research, 2, 96-98.

Dyer, K., \& das Nair, R. (2013). Why don't health professionals talk about sex? Journal of Sexual Medicine, 10(11), 2658-2670. https://doi.org/10.1111/j.1743-6109.2012.02856.x

Ekebergh, M. (2018). Att lära sig att vårda-med hjälp av reflexion och handledning [Learning to care-With the help of reflection and guidance]. Studentlitteratur. 
Ferrell, B., Ma, F., Malloy, P., Mazanec, P., \& Virini, R. (2016). Carers: AACN's new competencies and recommendations for educating undergraduate nursing students to improve palliative care. Journal of Professional Nursing, 32(5), 327-333.

Foronda, C., MacWilliams, B., \& McArthur, E. (2016). Interprofessional communication in healthcare: An integrative review. Nurse Education in Practice, 19, 36-40. https://doi.org/10.1016/j.nepr.2016.04.005

Gabrielsson, S., Sävenstedt, S., \& Olsson, M. (2016). Taking personal responsibility: Nurses' and assistant nurses' experiences of good nursing practice in psychiatric inpatient care. International Journal of Mental Health Nursing, 25, 434-443.

Garner, K., Goodwin, J., McSweeney, J., \& Kirchner, J. (2013). Nurse executives’ perceptions of end-of-life care provided in hospitals. Journal of Pain and Symptom Management, 45(2), 235-243. https://doi.org/10.1016/j.jpainsymman.2012.02.021

Gellerstedt, L., Medin, J., Kumlin, M., \& Rydell Karlsson, M. (2019). Sleep as a topic in nursing education programs? A mixed method study of syllabuses and nursing students' perceptions. Nurse Education Today, 79, 168-174. https://doi.org/10.1016/j.nedt.2019.05.030

George, T. P., DeCristfaro, C., \& Ford Murphy, P. (2020). Self-efficacy and concerns of nursing students regarding clinical experiences. Nurse Education Today, 90, 104401. https://doi.org/10.1016/j.nedt.2020.104401

Grant, M., \& Jenkins, L. (2014). Communication education for pre-licensure nursing students: Literature review 2002-2013. Nurse Education Today, 34(11), 1375-1381. https://doi.org/10.1016/j.nedt.2014.07.009

Grover, C., Mackasey, E., Cook, E., Tremblay, L., \& Loiselle, C. G. (2018). Patient reported care domains that enhance the experience of "being known" in an ambulatory cancer care centre. Canadian Oncology Nursing Journal, 28(3), 166-171. https://doi.org/10.5737/23688076283166171

Halldorsdottir, S. (2008). The dynamics of the nurse-patient relationship: introduction of a synthesized theory from the patient's perspective. Scandinavian Journal of Caring Sciences, 22, 643-652.

Hanssen, I. (2007). Omvårdnad i ett mångkulturellt samhälle [Nursing in a multicultural society]. Studentlitteratur.

Hofstede, G. (2010). Cultures and organizations: Software of the mind. McGraw Hill.

Holopainen, G., Nyström, L., \& Kasén, A. (2019). The caring encounter in nursing. Nursing Ethics, 26(1), 7-16. https://doi.org/10.1177/0969733016687161

Hussein, R., Salamonson, Y., Everett, B., Hu, W., \& Ramjan, L. (2019). Good clinical support transforms the experience of new graduates and promotes quality care: A qualitative study. Journal of Nursing Management, 27(8), 1809-1817. https://doi.org/10.1111/jonm.12880

Jahromi Kargar, M., \& Ramezanli, S. (2014). Evaluation of barriers contributing in the demonstration of an effective nurse-patient communication in educational hospitals of 
Jahrom, 2014. Global Journal of Health Science, 6(6), 54-60. https://doi.org/10.5539/gjhs.v6n6p54

Källberg, A.-S., Ehrenberg, A., Florin, J., Östergren, J., \& Göransson, K. (2017). Physicians' and nurses' perceptions of patient safety risks in the emergency department. International Emergency Nursing, 33, 14-19.

Kasch, C. R. (1986). Toward a theory of nursing action: Skills and competency in nurse-patient interaction. Nursing Research, 35(4), 226-230. https://doi.org/10.1097/00006199$\underline{198607000-00010}$

Knafo, A., Roccas, S., \& Sagiv, L. (2011). The value of values in cross-cultural research: A special issue in honor of Shalom Schwartz. Journal of Cross-Cultural Psychology, 42(2), 178-185. https://doi.org/10.1177\%2F0022022110396863

Kong, S. K. F., Wu, L. H., \& Loke A. Y. (2009). Nursing students' knowledge, attitude and readiness to work for clients with sexual health concerns. Journal of Clinical Nursing, 18, 2372-2382. https://doi.org/10.1111/j.1365-2702.2008.02756.x

Lundberg, K., Jong, M., Jong, M., \& Porskrog Kristiansen, L. (2020). Patients' experiences of caring encounter in health promotion practice: a qualitative study in Swedish primary health care. BMC Family Practice, 21(1). https://doi.org/10.1186/s12875-020-01296-6

Monaghan, T. (2015). A critical analysis of the literature and theoretical perspectives on theorypractice gap amongst newly qualified nurses within the United Kingdom. Nurse Education Today, 35(8), e1-e7. https://doi.org/10.1016/j.nedt.2015.03.006

Oermann, M. H., \& Gaberson, K. B. (2016). Evaluation and testing in nursing education. Springer.

O’Lynn, C., \& Krautscheid, L. (2011). "How should I touch you?” A qualitative study of attitudes on intimate touch in nursing care. American Journal of Nursing, 111(3), 24-31. https://doi.org/10.1097/10.1097/01.NAJ.0000395237.83851.79

Ortiz, J. (2016). New graduate nurses' experiences about lack of professional confidence. Nurse Education in Practice, 19, 19-24. https://doi.org/10.1016/j.nepr.2016.04.001

Östman, M., Bäck-Pettersson, S., J. Sundler, A., \& Sandvik, A.-H. (2021). Nurses' experiences of continuity of care for patients with heart failure: A thematic analysis. Journal of Clinical Nursing, 30(1), 276-286.

Parker, V., Giles, M., Lantry, G., \& McMillan, M. (2014). New graduate nurses' experiences in their first year of practice. Nurse Education Today, 34(1), 150-156. https://doi.org/10.1016/j.nedt.2012.07.003

Petges, N., \& Sabio, C. (2020). Perceptions of male students in a baccalaureate nursing program: A qualitative study. Nurse Education in Practice, 48, 102872. https://doi.org/10.1016/j.nepr.2020.102872

Råholm, M. B., Hedegaard, B. L., Löfmark, A., \& Slettebø, Å. (2010). Nursing education in Denmark, Finland, Norway and Sweden: From bachelor's degree to PhD. Journal of Advanced Nursing, 66(9), 2126-2137. 
Rask, M., Albinsson, G., Safipour, J., Wenneberg, S., Andersson, L., Carlsson Blomster, M., Ozolins, L.-L., Borg, C., \& Lindqvist, G. (2018). Validation of the verbal and social interaction questionnaire for nursing students: The focus of nursing students in their relationship with patients. Journal of Nursing Education and Practice, 8(4), 81-88. https://doi.org/10.5430/jnep.v8n4p89

Rask, M., \& Brunt, D. (2006). Verbal and social interactions (VSI) in Swedish forensic psychiatric nursing care as perceived by the patients and nurses. International Journal of Mental Health Nursing, 15, 100-110.

Rask, M., \& Brunt, D. (2007). Verbal and social interactions in the nurse-patient relationship in forensic psychiatric nursing care: A model and its philosophical and theoretical foundation. Nursing Inquiry, 14(2), 169-176. https://doi.org/10.1111/j.1440$\underline{1800.2007 .00364 . x}$

Rega, M. L., Telaretti, F., Alvaro, R., \& Kangasniemi, M. (2017). Philosophical and theoretical content of the nursing discipline in academic education: A critical interpretive synthesis. Nurse Education Today, 57, 74-81.

Rolt, L., \& Gillett, K. (2020). Employing newly qualified nurses to work in hospices: A qualitative interview study. Journal of Advanced Nursing, 76(7), 1717-1727. https://doi.org/10.1111/jan.14359

Salminen, L., Stolt, M., Saarikoski, M., Suikkala, A., Vaartio, H., \& Leino-Kilpi, H. (2010). Future challenges for nursing education: A European perspective. Nurse Education Today, 30(3), 233-238. https://doi.org/10.1016/j.nedt.2009.11.004

Saunamäki, N., \& Engström, M. (2013). Registered nurses' reflections on discussing sexuality with patients: responsibilities, doubts and fears. Journal of Clinical Nursing, 23, 531540 .

SFS [Ministry of Education and Research, Sweden]. (1993). Högskoleförordningen (1993:100) [The higher education ordinance (1993:100)]. Utbildningsförlaget.

Socialstyrelsen [National Board of Health and Welfare, Sweden]. (2020). Legitimation och särskilt förordnande [License to practice and special certification]. https://vemfargoravad.socialstyrelsen.se/sida/legitimation-och-sarskilt-forordnande

Spiva, L. A., Hart, P., Pruner, L., Johnson, D., Martin, K., Brakovich, B., McVay, F., \& Mendoza, S. (2013). Original research: Hearing the voices of newly licensed RNs, the transition to practice. American Journal of Nursing, 113(11), 24-32. https://doi.org/10.1097/01.NAJ.0000437108.76232.20

Swedish statute book [Svensk författningssamling]. (1977). Högskolelagen [The higher education bill]. Utbildningsförlaget.

Teaching Guidance Committee of Higher Education, Ministry of Education, China. (2018). National standards for undergraduate professional teaching quality (Part 2). Higher Education Press, 811-823.

Turkel, M. C., Watson, J., \& Giovannoni, J. (2018). Caring science or science of caring. Nursing Science Quarterly, 31(1), 66-71. https://doi.org/10.1177\%2F0894318417741116 
Wang, P., Ai, J., Davidson, P. M., Slater, T., Du, R., \& Chen, C. (2018). Nurses' attitudes, beliefs and practices on sexuality for cardiovascular care: A cross-sectional study. Journal of Clinical Nursing, 28(5-6), 980-986. https://doi.org/10.1111/jocn.14692

Whitford, H., Marland, G., Carson, M., Bain, H., Eccles, J., Lee, J., \& Taylor, J. (2020). An exploration of the influences on under-representation of male pre-registration nursing students. Nurse Education Today, 84, 1-5. https://doi.org/10.1016/j.nedt.2019.104234

World Health Organization. (2011). Standards and operational guidance for ethics review of health-related research with human participants. https://www.ncbi.nlm.nih.gov/books/NBK310666/

World Health Organization. (2020). WHO and partners call for urgent investment in nurses. https://www.who.int/news-room/detail/07-04-2020-who-and-partners-call-for-urgentinvestment-in-nurses

World Medical Association. (2013). Declaration of Helsinki: Ethical principles for medical research involving human subjects. Journal of the American Medical Association, 310(20), 2191-2194.

Zhang, M., Ge, L., \& Rask, M. (2019). Cross-cultural adaptation and psychometric testing of the Verbal and Social Interaction Questionnaire: A cross-sectional study among nursing students in China. Journal of Clinical Nursing, 28(11-12), 2181-2196. https://doi.org/10.1111/jocn.14811

Zhang, W., \& Liu, Y. L. (2016). Demonstration of caring by males in clinical practice: A literature review. International Journal of Nursing Sciences, 3(3), 323-327. https://doi.org/10.1016/j.ijnss.2016.07.006 